\title{
Vejledningens transformative potentiale i et overgangsperspektiv
}

Søren Nygaard Drejer ${ }^{1}$, Uddannelsesvidenskab, Syddansk Universitet

Anne Bang-Larsen, Uddannelsesvidenskab, Syddansk Universitet

\begin{abstract}
Denne artikel præsenterer baggrund, fund og resultater fra to casestudier af vejledning i skriveprocesser $\mathrm{i}$ et overgangsperspektiv. Overgange mellem uddannelsesniveauer kan være kritiske for elever og studerende, og i vejledningsforskningen har overgangen mellem gymnasium og universitet været underbelyst. Artiklen giver et indblik i elevers erfaringer med vejledning af skriveprocesser fra gymnasiet og undersøger, hvordan disse erfaringer aktualiseres i overgangen til universitetet. Undersøgelsen skriver sig ind i et forskningsfelt om vejledning, feedback og skrivedidaktik. Deweys erfaringsbegreb og Mezirows kommunikative læringsforståelse bruges til at identificere, hvordan vejledning bidrager til skrive(r)udvikling. På baggrund af dette diskuterer vi, hvad vi kan lære af de vejledningserfaringer, som eleverne kommer med fra gymnasiet, og vi giver et bud på, hvordan man i vejledning på universitetet kan adressere nogle af de udfordringer, der knytter sig til det institutionelle rammeskifte. Artiklen er derfor både særdeles relevant af interesse for forskere med interesse for vejledning i et overgangsperspektiv og for vejledere, der gerne vil kvalificere deres praksis med vejledning af skriveprocesser.
\end{abstract}

\section{Introduktion}

Hvad er god vejledning af skriftlige opgaver? Hvilke forventninger knytter sig til vejledningen, og hvilke antagelser hviler de på? Spørgsmål af denne karakter rejses hyppigt i forbindelse med vejledning, og med god grund, idet vejledning fra et institutionelt perspektiv ofte synes at være løsenet $\mathrm{i}$ forhold til at stilladsere studerendes faglige udvikling (Kiley 2011; Bastalich 2019). Svarene er mangfoldige og afhænger af, hvem man spørger og ikke mindst hvornåri et uddannelsesforløb, der spørges. I denne artikel gives et indblik i vejledtes fortællinger om vejledning $i$ et overgangsperspektiv, idet vi giver stemme til en gymnasieelev i 3.g og en førsteårsstuderende. ÆErindet er at undersøge, hvilke vejledningserfaringer unge mennesker bringer med sig ind på bacheloruddannelsen, og hvilke vejledningsbehov der kan identificeres på deres første år på universitetet. Antagelsen er, at en indsigt i elevers og studerendes erfaringsdannelser $\mathrm{i}$ et overgangsperspektiv kan være med til at kvalificere vejledning af førsteårsstuderende.

\footnotetext{
${ }^{1}$ Kontakt: snd@sdu.dk
} 


\section{Viden om vejledning af skriveprocesser}

Når nye studerende påbegynder bacheloruddannelsen, møder de op med erfaringer i forhold til vejledning af skriftlige opgaver og projekter, som rækker tilbage til folkeskolens projektopgave og gymnasiets arbejde med de større, flerfaglige og studieforberedende opgaver. Disse opgaver skrives i det 3-årige forløb på STX: Danskhistorieopgaven i 1.g (DHO), Studieretningsopgaven i 2.g (SRO) og Studieretningsprojektet i 3.g (SRP). Opgaverne er længere, har et akademisk og interdisciplinært format, og er forbundet med en høj grad af frihed til emnevalg. Opgaverne skrives i en undervisningsfri periode delvist udenfor skolens fysiske rammer, skrives under vejledning af lærerne i de to indgående fag og forsvares mundtligt. Forskningsmæssigt er arbejdet med disse opgaver belyst af Zeuner (2010), Krogh (2016), Drejer (2018), Bang-Larsen (2021) og Bang-Larsen \& Drejer (2021). Da vejledning af opgaveskrivningsprocesser på ungdomsuddannelserne hidtil kun har været belyst $i$ meget begrænset omfang, trækker artiklen på vejledningsforskning fra de mellemlange og videregående uddannelser.

Vejledning af opgaveskrivningsprocesser på de mellemlange og videregående uddannelser er et forskningsfelt i vækst. I en international kontekst gives et overblik over forskningsfeltet bl.a. af Pearson (2005) og Bastalich (2019). I en skandinavisk kontekst ser vi en lignende afdækning, foretaget af Wichman-Hansen og Eika (2007). Begge parter peger på en optagethed af vejledningsrelationernes betydning for læring (Delamont, Parry \& Atkinson 1998; Lee 2008; Gatfield 2005; Bengtsen 2018). Endvidere peger Bastalich på en udpræget interesse for pædagogiske modeller for, hvordan vejledning kan facilitere faglig udvikling (Pearson \& Brew 2002; Boud \& Lee 2005; Lee \& Green 2009). Endelig ser vi i forskningslitteraturen en interesse i subjektiveringer og positioneringer i vejledningssituationen, herunder også, hvordan vejledning kan bidrage til akademisk indkulturering (Green 2005; Petersen 2007; Bengtsen 2018).

Forventningerne til vejledningens transitionspotentiale ses både inden for de enkelte vejledningsforløb, gennem de enkelte uddannelsesforløb og i overgangene fra én uddannelse til en anden. Og det er en udbredt opfattelse, at vejledning er en betydningsfuld arena for akademisk indkulturering (Petersen 2007; Batalich 2019). Forskning viser imidlertid også, at overgange mellem uddannelsesniveauer kan være problematiske for både elever på ungdomsuddannelserne og studerende på de videregående uddannelser (Ebbensgaard, Jacobsen \& Ulriksen 2014a; Krogh, Christensen \& Jakobsen 2015; Krogh 2014). Ask fremhæver blandt andet vejledning knyttet til skriftlige opgaver som et vigtigt element i en vellykket overgang til videregående uddannelser (Ask 2007).

\section{Viden om skriveprocesser og skriverudvikling i et overgangsperspektiv}

Evaluerings- og feedbackbegrebet er tæt knyttet til vejledning, baseret på forestillingen om, at vejledte kan udvikle sig gennem effektiv feedback (Emilsson \& Johnsson 2007; Dixon \& Hanks 2010; Walker \& Thomson 2010). Indenfor vejledningsforskningen er der ikke konsensus om, hvad der forstås ved effektiv feedback, og hvordan den bør gives, men skrivedidaktikken har bidraget med indsigt i, hvordan feedback på skriftlighed kan stilladsere en faglig udvikling. Artiklen trækker i særlig grad på det danske skriveforskningsprojekt "Faglighed og skriftlighed", som blandt andet har beskæftiget sig med skrivning i ungdomsuddannelserne og skrivning i overgange (Krogh, Christensen \& Jakobsen 2015; Krogh \& Jakobsen 2016; Drejer 2018).

Forskning i overgange mellem uddannelsesniveauer fokuserer hyppigt på den studerendes færdigheder og indholdet i den uddannelse, som den studerende starter på (Lunsford \& Lunsford 2008; Ask 2007; Clughen \& Hardy 2012). En anden tilgang til feltet interesserer sig for overgange som bredere akademiske indkulturerings- 
processer, der ud over fagligt indhold blandt andet også inddrager studerendes identifikations-processer (Lea \& Street 1998; Ivanic 1998; Lillis 2001; Robinson-Pant \& Street 2012; Lea 2012; Holmegaard, Madsen \& Ulriksen 2014b; Nelson \& Castello 2012; Castello \& Inesta 2012). Prior og Bilbro (2012) udpeger tre overordnede perspektiver i indkultureringen knyttet til akademisk skrivning på universitetet: indkultureringens indhold, det vil sige den faglige viden og de faglige praktikker i faget og på studiet, indkultureringens fysiske rum samt læring og udvikling. En central pointe er, at alle disse perspektiver er knyttet sammen og er væsentlige aspekter af de studerendes bevægelse ind i deltagelse i faget på universitet. Holmegaard, Madsen og Ulriksen (2014a), der har undersøgt overgange fra gymnasium til videregående uddannelser i STEM-fag, føjer til dette, at identitetsprocesser også spiller en vigtig rolle i de studerendes narrativer om overgangen til studiet.

Et andet vigtigt bidrag til forskning i skriveprocesser i et overgangsperspektiv, der også finder, at udvikling, læring og identifikationsprocesser er knyttet sammen med akademisk indkulturering, er Sommers og Saltz (2004). I deres undersøgelse af studerendes indkulturering på college ser de, at studerende, der opfatter sig selv som novicer i akademisk skrivning, har lettest ved at tilegne sig og udvikle deres akademiske skrivning, idet de er mere åbne over for tilegnelse af nye faglige, skriftlige redskaber, og de er i højere grad åbne overfor feedback. Desuden finder Sommers og Saltz, at de studerendes opfattelse af formålet med de stillede opgaver er væsentlig for skrivernes tilegnelse af akademisk skriftlighed. Fra skriveforskningen tager vi med os, at både det faglige indhold, de studerendes positionering og deres identifikationsprocesser, er væsentlige faktorer for deres skrive(r)udvikling. Vi antager, at disse elementer også er væsentlige i tilknytning til vejledning af skriveprocesser $i$ et overgangsperspektiv, hvor den studerende gennem vejledning givetvis kan stilladseres til en mere selvstændig deltagelse i faget.

Skriveforskningens undersøgelser af overgangsperspektiver gør det evident, at der også er behov for at undersøge vejledning af skriveprocesseri overgangen mellem uddannelser. På den baggrund stilles forskningsspørgsmålet:

Hvilke vejledningserfaringer bringer studerende med sig i overgangen fra gymnasiet til universitetet, og hvordan kan disse erfaringer aktualiseres i vejledning af skriveprocesser på universitetet med henblik på at fremme vejledningens transformative potentiale?

\section{Teoretisk rammeværk til undersøgelse af vejledningsprocesser}

Artiklens teoretiske ramme baseres på Deweys erfaringsbegreb og Mezirows kommunikative læringsforståelse.

Hos Dewey er læring forstået som begrebslig rekonstruktion af erfaring, erfaringsdannelse, og har både en refleksions- og en handlingsdimension. Deweys læringsteori er interessant for en analyse af vejledning af skriveprocesser, fordi vi med hans begrebsapparat kan pege på vejlederen som facilitator af kontinuiteten $\mathrm{i}$ erfaringsdannelsen (Dewey 2000). Erfaringsdannelsen bliver et organisk samspil mellem den lærendes tidligere og nuværende erfaringer, og et samspil mellem den lærende og omgivelserne (Dewey 2000). Læringen bliver metaforisk forstået som vækst. I erfaringsdannelsen er den lærende i udveksling med omgivelserne og har brug for stilladsering gennem input fra vejleder. I en vejledningskontekst betyder det en interesse for, hvilke tidligere vejledningserfaringer den studerende bringer med ind i vejledningen ved starten af bacheloruddannelsen, og hvordan disse adskiller sig fra de nye vejledningserfaringer, erhvervet i samspil med den nye kontekst $\mathrm{i}$ overgangen til universitetet. Dette adresserer kontinuitetsdimensionen i erfaringsdannelsen. Vi interesserer os ligeledes for, hvordan dialogen mellem den studerende og vejlederen udspiller sig: hvordan adresserer den 
studerende og vejledere tidligere erfaringer i dialogen, og hvordan skaber deltagerne kontinuitet i dialogen? Dette adresserer samspilsdimensionen i erfaringsdannelsen.

Mezirow trækker blandt andet på Deweys erfaringsbegreb i sin analyse af transformativ læring (Mezirow 2012: 156ff). Udgangspunktet er begrebet meningsperspektiv, der betegner en fortolkningsramme, som den lærende forstår nye erfaringer inden for. En central pointe hos Mezirow er, at meningsperspektiver er foranderlige: Gennem reflekterede handlinger vurderer den lærende de antagelser, der mere eller mindre bevidst ligger i meningsperspektiverne. Dette kan ske ved mødet med et problem, der ikke kan forstås inden for de eksisterende meningsperspektiver. En sådan krise giver mulighed for kritisk refleksion over forudsætningerne for tidligere erfaringsdannelse og læring. Herved kommer der et element af kontinuitet $\mathrm{i}$ udviklingen af meningsperspektiverne, jvf. Deweys erfaringsbegreb. I sidste ende giver en sådan kritisk refleksion den studerende mulighed for gennem en reflekteret handling at ændre meningsperspektiverne, så de i højere grad kan bruges til at forstå og løse de nye problemer, der ikke kunne rummes inden for de gamle rammer. Ænndringen i meningsperspektiverne er, som hos Dewey, en vækstproces, der sker i samspil med omgivelserne. Mezirow betegner processen perspektivomdannelse, som er et eksempel på transformativ læring.

Dewey og Mezirow introducerer ikke begreber, der konkret kan anvendes i analysen af vejledningshændelsernes deltagelsesdynamikker. For mere konkret at undersøge de vejledtes erfaring og erfaringsdannelse i vejledningen benytter vi os derfor af Olga Dysthes begreb optag til på mikroniveau at udpege, hvordan vejledningsdialogen adresserer erfaringsdannelsen (Gamoran \& Nystrand 1991; Dysthe 1997). Dysthe benytter begrebet til at betegne det forhold, at vejleder inkorporerer elevens svar i den efterfølgende respons og omvendt, hvorved vejledningssamtalen får dialogisk karakter (Bakhtin 1981; Dysthe 1997). Optag er dermed en måde at identificere deltagelsesdynamikker på, men da optag udelukkende retter sig mod den erfaringsdannelse, der eksternaliseres gennem samtale, kan begrebet ikke bruges som en entydig indikator for læring. Til undersøgelse af, hvordan de vejledte oplever, at vejledning bidrager til udvikling i skriveprocessen, trækker vi derfor også på de analytiske begreber position og indkulturering.

Med vores teoretiske positionering fremhæver vi begreberne erfaringsdannelse, meningsperspektiv, kritisk refleksion, transformativ læring samt perspektivomdannelse som centrale for forståelsen af, hvordan vejledning bidrager til transformation i skriveprocesser. I vejledningen kan den vejledte positioneres som en deltager, der kritisk reflekterer over sine meningsperspektiver og dermed over sin læring. Denne kritiske refleksion giver mulighed for erfaringsdannelse forstået som etablering af sammenhænge mellem tidligere og nuværende erfaringer og som udvikling af nye erfaringer. Processen betegner Mezirow som transformativ læring, og den kan betragtes som en del af en indkulturering. I indkultureringsprocessen har identifikation en væsentlig funktion (Prior \& Bilbro 2012): For at den vejledte skal kunne reflektere kritisk over sit meningsperspektiv, skal hun identificere sig med en lærende i faget, det vil sige med en deltager, der i større eller mindre grad er novice, og som gerne vil være anerkendt deltager i den faglige kultur. 


\section{Datamateriale og metodisk tilgang}

Analysens empiriske grundlag

Artiklen baserer sig på reanalyser af to afrapporterede casestudier, hvor de to cases er udvalgt blandt andre mulige cases. ${ }^{2}$

De to cases udgøres af gymnasieeleven Lunas arbejde med Studieretningsprojektet og empirien fra den danskstuderende Veronikas opgaver på 1. år på bacheloruddannelsen. Disse to cases betragtes som kritiske cases (Flyvbjerg 2010). Den relativt tykke empiri (Geertz 1973; Yin 2011) giver en indsigt i de fortællinger, de vejledte formulerer og reformulerer i løbet af et vejledningsforløb. Vejledtes fortællinger er analysens forgrund, men reflekteres i institutions-, organisations- og vejlederperspektiver, der alle har betydning for vejledtes erfaringsdannelse. Kilder er anonymiseret, og fremstilles for sammenhængens skyld ud fra kategorierne Sydskolen og danskstudiet, vejledere og vejledte (Luna og Veronika).

Luna er gymnasieelev fra Sydskolen, et større oplandsgymnasium, hvor hun går i en samfundsfaglig studieretning. Luna deltog i ph.d. -projektet Vejledning i arbejdet med de storre skriftlige opgaver på STX, hvor vejledning af elevers opgaveskrivningsprocesser var i fokus. Data knyttet til Lunas vejledning omfatter læreplaner knyttet til SRP, de tre større tværfaglige opgaver (herunder også udkast undervejs i skriveprocessen), feedback på opgaver, observation af fem vejledninger, optag af virtuelle vejledninger og adgang til skriftlig kommunikation med vejledere. Endvidere er der i den 3-årige periode udført fem interviews med Luna, som tager afsæt i den observerede vejledning og den modtagne feedback på opgaven. Interviews er designet som talk-around-the-texts-interviews, der giver adgang til relativt udfoldede narrativer (Lillis 2008, Lillis 2009). Interviews tager afsæt i de tre opgaver og den feedback, Luna har fået. Data i fokus for denne artikel er data knyttet til Lunas arbejde med studieretningsprojektet i 3.g.

Veronika er studerende på bacheloruddannelsen i dansk, som hun påbegyndte umiddelbart efter gymnasiet. Veronika deltog i ph.d. -projektet Overgange og udviklinger. Data knyttet til Veronikas overgang og udvikling udgøres af samtlige opgaver skrevet i danskfaget i gymnasiet, de tre store opgaver i gymnasiet, samtlige opgaver på første år af bachelorstudiet, fire interviews foretaget under første år på studiet, observationer af undervisningen og af to vejledninger samt styredokumenter knyttet til undervisningen i gymnasiet og på bacheloruddannelsen.

\section{Undersøgelsens metodiske tilgang}

Analysens metodologiske afsæt er den narrative analyse, som muliggør fokus på udviklingen i de vejledtes narrativer over tid, hvilket er af interesse for casens longitudinale perspektiv. Tilgangen giver ligeledes indsigt $\mathrm{i}$ de sidestillede narrativer, der er i spil, når de vejledte konstruerer fortællingerne om deres vejledningsprocesser (Riessman 2008). Karakteristisk for tilgangen er en bred forståelse af narrativer samt en betoning af kontekstens betydning (Loseke 2007; Frank 2015).

Med analysen af de vejledtes narrativer ønsker vi at undersøge de vejledtes erfaringer med vejledning og deres fortællinger om, hvordan vejledning kan bidrage til transformation i skriveprocesser. Analysen af vejledtes

\footnotetext{
${ }^{2}$ For detaljeret præsentation af empiriens grundlag henvises til Drejer (2018), Bang-Larsen (2021b og 2021c) og Bang-Larsen \& Drejer (in press).
} 
fortællinger baseres på tre analysekategorier udledt på baggrund af Deweys, Mezirows og Dysthes teoretiske begrebsapparat: "hændelse", "indikator for udvikling" samt "erkendelse". Ved "hændelse" forstår vi konkrete, iagttagbare forhold ved vejledningen: Hvor foregår vejledningen, hvornår, hvor længe, hvilke medier og modaliteter indgår i vejledningen? Ved "indikator for udvikling" retter vi blikket mod de to cases' longitudinale perspektiv, og vi ser efter tegn på transformation hos den vejledte: Kan vi se tegn på, at den vejledte foretager reflekterede handlinger (Mezirow 2012)? Kan vi iagttage, at den vejledte reflekterer over elementer $i$ vejledningen? Peger den vejledte selv på elementer, som er afgørende for hendes indkulturering i faget? Dysthes begreb "optag" benyttes til at indfange dette, idet optag viser, hvordan deltagerne i dialogen involverer sig i samtalen. På mikroniveau kan begrebet mere konkret bruges til at udpege, hvordan deltagerne i vejledningssamtalen adresserer elevens og den studerendes tekst og spørgsmål og vejlederens feedback, og hvordan deltagerne adresserer den vejledtes erfaringsdannelse. Den tredje og sidste analysekategori, "erkendelse", forstås som ændring i meningsperspektiv og dermed et eksempel på transformativ læring (Mezirow 2012). Med analysekategorierne kan vi pege på, hvordan der i vejledtes narrativer etableres en fortælling om udvikling i skriveprocesser. Identifikation af dette kan bidrage med en indsigt i vejledtes tidligere erfaringer og kan danne grundlag for, at disse kan adresseres i en dialog i en ny vejledningskontekst.

\section{Analyse - Fortællinger om vejledning fra en elev i 3.9}

\section{Præsentation af casen}

Det følgende er en præsentation af væsentligste fund i tilknytning til den vejledning, Luna deltager i, i forbindelse med arbejdet med hendes studieretningsprojekt. Lunas studieretningsprojekt er skrevet i fagene samfundsfag og religion og omhandler Kinas undertrykkelse af religiøse minoriteter. Ærindet med analysen er at præsentere et eksempel på, hvilke vejledningserfaringer en elev har fra gymnasiet.

\section{Vejledningshændelser i tilknytning til Lunas skriveproces}

\begin{tabular}{|c|c|c|c|c|}
\hline & $\begin{array}{l}\text { Tidspunkt og } \\
\text { varighed }\end{array}$ & Deltagere & $\begin{array}{l}\text { Lokale } \\
\text { organisatoriske } \\
\text { rammer og krav }\end{array}$ & Fokus i samtalen \\
\hline $\begin{array}{l}\text { Første } \\
\text { vejledning }\end{array}$ & $\begin{array}{l}21.02 .2020 \\
\text { Forud for de to } \\
\text { vejlederes udformning } \\
\text { af opgaveformulering. } \\
15 \mathrm{~min} \text {. }\end{array}$ & $\begin{array}{l}\text { De to vejledere } \\
\text { (religionslæreren og } \\
\text { samfundsfagslæreren) } \\
\text { samt eleven. }\end{array}$ & $\begin{array}{l}\text { "Eleven medbringer } \\
\text { udkast til egen } \\
\text { problemformulering." }\end{array}$ & $\begin{array}{l}\text { Fokus for samtalen er at } \\
\text { drøfte elevens udspil til } \\
\text { en problemformulering. }\end{array}$ \\
\hline $\begin{array}{l}\text { Anden } \\
\text { vejledning }\end{array}$ & $\begin{array}{l}26.03 .2020 \\
\text { I skriveperioden efter } \\
\text { udlevering af opgave- } \\
\text { formuleringen. } \\
15 \text { min. }\end{array}$ & $\begin{array}{l}\text { De to vejledere og } \\
\text { eleven. }\end{array}$ & $\begin{array}{l}\text { Ingen instruks. Ingen } \\
\text { krav om skriftlige } \\
\text { forlæg. }\end{array}$ & $\begin{array}{l}\text { Samtalen har fokus på } \\
\text { empiri, metoder og } \\
\text { teorier til besvarelse af } \\
\text { opgaveformuleringen. }\end{array}$ \\
\hline
\end{tabular}




\begin{tabular}{l|l|l|l|l}
$\begin{array}{l}\text { Tredje } \\
\text { vejledning }\end{array}$ & $\begin{array}{l}\text { Vejledning over mail i } \\
\text { perioden 23.03.2020- } \\
\text { 02.04.2020, dvs. i } \\
\text { skriveperioden }\end{array}$ & $\begin{array}{l}\text { De to vejledere og } \\
\text { eleven. Telefonsamtaler, } \\
\text { dog kun } \\
\text { religionslæreren og } \\
\text { eleven. }\end{array}$ & $\begin{array}{l}\text { Ingen instruks, } \\
\text { vejledning finder sted } \\
\text { på elevens initiativ. }\end{array}$ & $\begin{array}{l}\text { Fokus er besvarelse af } \\
\text { elevens spørgsmål. } \\
\text { Spørgsmålene er en } \\
\text { blanding af formalia- } \\
\text { spørgsmål, ønske om } \\
\text { hjælp til kilder og } \\
\text { spørgsmål, som skal } \\
\text { bekræfte eleven i, om } \\
\text { hun griber de enkelte } \\
\text { elementer i opgaven an } \\
\text { på en hensigtsmæssig } \\
\text { måde. }\end{array}$ \\
\end{tabular}

Tabel 1: Rammer og indhold for vejledningshændelser knyttet til Lunas arbejde med studieretningsprojektet

Lunas vejledningsproces over det 3-årige gymnasieforløb afspejler ikke en lineær indkulturering, men vidner om, at nogle af vejledningstematikkerne genspilles i forskellige variationer, mens andre udtones. Analyserne viser, at eleven i slutningen af sit gymnasieforløb har tilegnet sig en genreforståelse og annammet den faglige diskurs. Hun positionerer sig selv med autoritet som skriver. Arbejdet med opgaverne i den 3-årige periode har delvist bekræftet hende i en oplevelse af at være indkultureret i gymnasiet og at kunne honorere kravene til de større tværfaglige opgaver, hvilket knyttes til hendes identifikation med fagene. Tidligere erfaringer med vejledning og skrivning har betydning for Lunas tilgang til både vejlednings- og skriveproces: Hun har indsigt $i$, hvor hendes udfordringer er, og hun reflekterer det kritisk i vejledningsprocessen (Bang-Larsen \& Drejer in press). Analysen af Lunas narrativ peger imidlertid også på, at Luna, til trods for de positive skriveerfaringer, møder opgaveskrivningen med stor usikkerhed og et behov for, at vejledningen skal bekræfte hendes oplevelse af at være indkultureret (Bang-Larsen 2021). Usikkerheden angår vejledningssituationen og de faglige forventninger knyttet til den. Endvidere er usikkerheden af faglig karakter, som spænder over alt fra materialevalg til disponering og opgaveløsning. Nedenfor udpeges, hvordan vejledningen i 3.g adresserer de udfordringer, Luna oplever, og hvilke nye meningsperspektiver, det bringer med sig.

\section{Hvilke indikatorer for udvikling ser vi i vejledning af skriveprocesserne?}

Analysen af Lunas fortælling om sin vejledning følger to spor, som fletter sig ind i hinanden. Det ene spor er den konkrete vejlednings- og skriveproces og Lunas egne identifikationer af, hvad hun har brug for hjælp til. Dette spor illustrerer Lunas kritiske refleksion og meningsperspektiv. Det andet spor omhandler affektive elementer knyttet til vejlednings- og skriveprocessen og er fortællingen om, hvordan Luna gennem vejledningen søger at blive bekræftet i en position som indkultureret. Denne del af narrativet adresseres indirekte i både vejledningssamtale og interviews.

Vejledningssamtalerne er præget af variation i indhold og vejlederes/vejledtes positioneringer. Lunas spørgsmål er både rettet mod meget overordnede tematikker som analysestrategi og kildevalg, og mod helt konkrete tematikker, karakteriseret som formalia. For hovedparten af spørgsmålene gælder det, at Luna søger bekræftelse i forhold til, om hun har gjort det rigtigt. Vejlederne responderer imidlertid meget forskelligt, idet den ene vejleder har den strategi, at hun besvarer vejledtes spørgsmål, hvorved samtalen får en instruktiv karakter, men dog også vidner om optag. Den anden vejleder bedriver en udfordrende vejledningsdidaktik samtidig med, at 
hun er optaget af på et mere affektivt niveau at bekræfte Luna og indgyde hende selvtillid, hvorved hun understøtter Lunas position som indkultureret.

Lunas valg af emne og fag er knyttet til, at vejlederne i forbindelse med Dansk-historieopgaven (1.g) og Studieretningsopgaven (2.g) har opfordret hende til "at udfordre sig selv noget mere" (feedback på DHO). Dette er et tilbagevendende tema i interviews. Emnevalget vidner om en refleksiv handlen og perspektivomdannelse, som afstedkommer et opgavevalg, der både udfordrer hende, og som hun tilgår med autoritet og ejerskab:

Luna: Altså det er meget $X$, der har sagt det, at jeg skulle udfordre mig selv og sådan vælge noget at... ja, hvor jeg ikke var sikker på, at jeg lige havde styr på det hele og sådan noget, og så fik jeg egentlig interesse for det her. Men jeg var i tvivl, om jeg kunne finde kilder nok til det, og om det var for svært og sådan i forhold til samfundsfag. Der synes jeg også det er lidt svært med de der IP-teorier [teorier om international politik], og det var jo dem, jeg ligesom skulle bruge i det, men ja, så tænkte jeg ligesom på det her med sådan og prøve at udfordre mig selv lidt og kaste mig ud i noget, jeg ikke lige sådan var helt sikker på, jeg kunne finde ud af, og så besluttede jeg mig så for at vælge det.

(Luna, interview nr. 2)

Arbejdet med opgaven er forbundet med en høj grad af både engagement og selvstændighed, samtidig med at der knytter sig en usikkerhed i forhold til, om hun kan honorere kravene knyttet til opgaven. Vi fremdrager to forhold fra analysen til illustration af, hvordan disse udfordringer tematiseres i vejledningen. Det ene forhold angår valg af empiri i religionsfaget, og det andet angår det samfundsfaglige teorivalg.

I den første vejledning ansporer vejleder Luna til at fortælle om, hvilke udfordringer hun oplever lige nu:

Religionslærer: Hvad er vigtigt for dig lige nu?

Luna: Mest og få styr på mine kilder, tror jeg.

Religionslærer: Ja?

Luna: Og så lige at finde ud af, hvad der ligesom skal være hvor.

Religionslærer: Hvordan fremstiller du?

Luna: Altså, hvad der skal være redegørelse og hvad der skal være analyse og sådan?

Religionslærer: Ja.

Luna: Jeg er lidt i tvivl i forhold til civilreligion, om jeg sådan ligesom skal redegøre for teorien og så analysere Kina, eller om jeg skal redegøre for civilreligionen i Kina, altså når teorien ligesom går på USA?

Religionslærer: Ja...

Luna: Om jeg så skal redegøre for den teori?

Religionslærer: Ja, hvis jeg kender dig ret, så har du læst den dér bog om civilreligion, det der Bella... 
Luna: Ja.

Religionslærer: Og så tror jeg vil spørge dig, er det sådan, at du synes, du skal have redegjort for det?

Luna: Det ved jeg ikke, altså om jeg selv synes, jeg skal have redegjort for det... ikke sådan uddybende, måske bare sådan kort?

Religionslærer: Okay, men så tror jeg sådan set, du svarer på det selv.

Luna: Ja?

Religionslærer: Du skal have en kort redegørelse, og så skal du ellers bare anvende det.

Citatet er interessant, idet vi ser en vejleder arbejde ud fra en udfordrende vejledningsdidaktik, hvor hun søger at få eleven til gennem kritisk refleksion at nå en erkendelse, ud fra en hensigt om at styrke elevens oplevelse af sig selv som selvstændig, arbejdsom og kompetent. Passagen illustrerer imidlertid, at det konkrete tvivlsspørgsmål, eleven adresserer, ikke besvares direkte i løbet af vejledningssamtalen. Da vejlederen ikke besvarer Lunas spørgsmål, og de spørgsmål og kommentarer, som vejleder bibringer samtalen, peger i en anden retning, kan man diskutere graden af optag og dermed også graden af kontinuitet i erfaringsdannelsen. Det er i den sammenhæng også interessant, at eleven ved vejledningssamtalens afslutning bliver bedt om at sammenfatte, hvad hun skal arbejde videre med nu. Her responderer Luna med følgende: "altså lige have slået sådan min vinkel helt fast, tror jeg, og så have fundet mit materiale... ja og ligesom have styr på al grundviden eller sådan det baggrundsviden til det, jeg godt vil". Citatet er en reproduktion af de udfordringer, Luna nævnte ved vejledningssamtalens begyndelse, hvilket leder tankerne hen på, om vejledningssamtalen overhovedet har givet anledning til kritisk refleksion, der skaber udvikling i hendes skriveproces og dermed perspektivomdannelse. Samtidig er det bemærkelsesværdigt, at der i hele vejledningssamtalen er en udpræget tendens til, at vejledte svarer med et bekræftende "ja" på vejleders spørgsmål og kommentarer, men at eleven ved anden vejledning vender tilbage til de samme spørgsmål (Lunas forberedelsesark til anden vejledning). Dette peger direkte ind i vejledningssituationens dilemma, idet vejledningssamtalen på den ene side lægger op til en samtale, hvor vejledte frit kan bringe spørgsmål og refleksioner i spil, men på den anden side også er en situation, hvor vejleder i sidste ende bedømmer vejledtes produkt. Desuagtet at bestræbelsen i vejledningssamtalen er symmetrisk og dialogisk, illustrerer sekvensen dialogens udfordringer. Sekvensen viser, hvordan fraværet af fælles hensigt og gensidigt optag afstedkommer, at vejledningen ikke har transformativt potentiale. Denne tolkning understøttes af interviews med eleven.

I andre dele af vejledningshændelserne ser vi imidlertid en vejledningsdialog, der giver anledning til refleksion, og ansporer en udvikling i Lunas arbejde med opgaven. Dette ser vi bl.a. i den videre del af vejledningssekvensen ovenfor, hvor samfundsfagsvejlederen efter noget tid afbryder samtalen mellem religionsvejlederen og Luna:

Samfundsfagslærer: Nå, samfundsfag, det er A-niveau-faget.

Luna: Ja.

Samfundsfagslærer: Det fag skal jo selvfølgelig have noget fylde også, og der siger du, at der vil du gerne kigge på, hvorfor omverdenen ikke reagerer. 
Luna: Ja

Samfundsfagslærer: Hvem tænker du, når du siger omverden?

Luna: Altså, jeg tænker sådan både sådan storaktør som for eksempel USA, men også sådan organisationer, sådan FN for eksempel.

\section{Samfundsfagslærer: Okay?}

Luna: Ja...

Samfundsfagslærer: Ja, fordi det vil helt klart være mit forslag til dig, at du snævrer det ind, fordi omverden det er netop mange forskellige ting (...) man kan for eksempel tage $\mathrm{FN}$, eller man kan tage USA, eller vi kan kigge på Danmarks forhold i forhold til Kina eller alt mulig andet. Hvad tænker du, at du gerne vil have i spil rent samfundsfagligt $\mathrm{i}$ forhold til at kigge på det?

Luna: Altså noget med sådan IP-teorier, og sådan lave en analyse ud fra det?

Samtalen vidner om optag hos både vejleder og elev, idet vejleder griber fat i det tvivlsspørgsmål, Luna tidligere adresserede, hun beder Luna overveje og definere omverdensbegrebet, og på det grundlag diskuterer de relevant materiale. I de videre vejledningsprocesser og skriveprocesser vender Luna og samfundsfagsvejlederen tilbage til dette forhold på forskellige niveauer - både i forhold til skriveprocessen, men også i forhold til materialevalg, hvor Luna beder om hjælp. I tredje vejledning peger vejleder således på, hvordan skriveprocessen kan være med til at klarlægge, hvilke teorier der er relevante på hvilke niveauer:

Det kan godt være, at du i skriveprocessen bliver nødsaget til at gå tilbage til din redegørelse og enten slette eller tilføje afsnit her, idet du måske i dit analysearbejde finder ud af, at der er nogle begreber/teorier, som du alligevel ikke fik i spil, eller omvendt, at der er begreber, du bliver nødsaget til at skrive ind i din redegørelse, da du finder ud af, at de faktisk var ret centrale for at lave en fyldestgørende analyse. (klip fra mailkorrespondance mellem Luna og samfundsfags-vejleder vejledning 3).

Den videre skriveproces kan tolkes som et udtryk for en kritisk refleksion ansporet af samfundsfagsvejlederen. Lunas skrivning udvikler sig til at blive undersøgende og udforskende. Heri ligger der en tydelig perspektivomdannelse. I modsætning til de tidligere større skriftlige opgaver skriver Luna ikke sin SRP lineært hun tilegner sig begreber, som fx IP-teorierne, og tildeler dem autoritet gennem skrivning:

Luna: Altså, jeg startede med at... ja, det var egentlig meget sådan, at jeg startede lidt med min analyse faktisk... eller nej... jeg skrev allerførst min redegørelse om civilreligion, og så inden jeg gik i gang med min redegørelse for IP-teorierne [international politik], så lavede jeg sådan lidt af min analyse. Fordi at jeg har jo kun redegjort for nogle af de IP-teorier, der findes, fordi jeg kun vil redegøre for dem, jeg kom til at bruge i min analyse. Så derfor så blev den lidt sådan bagvendt dér, så først dér læste jeg sådan op på alle IP-teorierne, så jeg havde lige sådan en overordnet ide om, hvad det lige var, de gik ud på, de forskellige, og så begyndte jeg at analysere nogle af mine kilder, nogle af de kilder jeg brugte til analysen, og så ligesom den vej fandt ud af, hvad for nogle IP-teorier jeg synes var relevante, og så skrev jeg så redegørelsen for dem. (Luna, interview nr. 2) 
Analyserne viser betydningen af gensidigt optag hos elever såvel som vejledere. Ligeledes viser de, at eleven i vejledningsprocessen har meget forskelligartede behov for vejledning:

Luna: Altså, jeg vil sige, da XX [religionsvejlederen] hun hjalp mig med at finde den der kilde til min diskussion, der... det var virkelig fordi... der... altså der havde jeg virkelig brugt lang tid på at lede efter det, og jeg kunne bare ikke finde det jeg søgte, og jeg synes ikke sådan jeg kunne finde det rigtige og søge efter, og så hjalp hun mig med at finde den der, som jeg bare synes lige... altså lige passede til det, jeg gerne ville have og sådan noget. (Luna, interview nr. 2)

Interviewuddraget viser betydningen af, at en vejledningsdidaktik tilpasses den konkrete elevs situation og det formål eleven har med vejledning. Endelig peger analyserne også på, at til trods for, at eleven går i 3.g, og i overvejende grad positionerer sig selv som indkultureret, så efterspørger hun også en anvisende og instruktiv vejledning som et bidrag til hendes refleksionsproces. Dette til trods for, at hun udviser selvstændighed i forhold til emnevalg $\mathrm{mm}$.

\section{Andring i meningsperspektiv - erkendelse}

Analysen viser, at Luna gennemgår en markant udvikling som opgaveskriver. Dette tydeliggøres blandt andet $\mathrm{i}$ den måde, hun tager autoritet på i forhold til skrivningen af sit projekt, hvilket vi ser i emnevalg, genreforståelse og tilegnelse af faglige begreber, teorier og metoder. I løbet af de tre år i gymnasiet ser vi ligeledes en udvikling i Lunas brug af vejledning. Man kan tale om en ændring i Lunas meningsperspektiv, som er knyttet til de erfaringer, hun har gjort sig, som hun reflekterer kritisk over. Luna bliver mere opsøgende og spørger vejleder til råds undervejs i processen, hvor hun har brug for det. Luna begynder at stille spørgsmål og bede om hjælp til de ting, hun har svært ved. Det vil sige, at hun får en mere tillidsfuld relation til sine vejledere:

Luna: Og så tror jeg også mere, jeg har benyttet mig af i den her opgave end de andre opgaver sådan og stille spørgsmål til dem løbende (...) Jeg tænkte, sådan inden jeg skrev, om det der... fordi jeg var helt... jeg havde... jeg kunne slet ikke finde det der med kilder og sådan noget, så inden jeg skrev til XX [religionsvejlederen], tænkte jeg sådan, om man sådan burde kunne finde ud af det, selvom det sådan ville... ja om hun ville tænke, det sådan var dårligere, fordi jeg havde haft brug for hjælp til, eller havde haft brug for at spørge om hjælp til at finde det. Men ja, så tænkte jeg, at det var nok også noget pjat, og så spurgte jeg så om det alligevel... men sådan jeg overvejede lige sådan, om det sådan trækker ned i deres syn på opgaven, eller hvad man siger, hvis man sådan har brug for at spørge om hjælp til sådan og komme videre. (Luna, interview nr. 2)

Lunas narrativ om vejledning præges imidlertid også af erkendelser i forhold til de behov, hun ønsker, at vejledning skal tilgodese. Hun peger på det problematiske forhold i vejledningen, at fokus og forventninger fra vejledernes side ikke er entydigt, og at hun "savner dybde" i vejledningen. Hun efterlyser elementer, som kan imødekomme hendes ønske om bekræftelse og skabe tryghed $\mathrm{i}$ hendes proces:

Luna: Hvis det havde været sådan lidt mere ... for nogle gange synes jeg, det har været sådan lidt uhåndgribeligt, hvad det lige er, man skal til vejledningen, og hvor langt man skal være nået. Og fordi det er også lidt det, når man... når man... altså, vi havde den der ene vejledning inden og så den vejledning i skriveperioden, og så kunne man jo så stille spørgsmål ud over det. Men der har ikke været den der sådan dybdegående vejledning ud over det [...] Det kunne måske have været fint nok, fordi sådan, ja, hvis nu man kunne sådan præsentere et eller andet... eller sådan sige, at jeg har skrevet det 
her indtil videre, og sådan lige få sådan praj om, om man var på rette vej. Fordi det tror jeg også lidt, jeg har følt, især i den her virkelig lange opgave, sådan hvor jeg har siddet og skrevet og skrevet, og nogle gange har jeg også tænkt sådan... altså gad vide, om jeg bare er altså på vej den helt forkerte retning, så det kunne måske have været fint, hvis man sådan kunne komme med et udkast til et eller andet og lige sådan få noget feedback på det. (Luna, interview nr. 2)

Citatet peger netop på en erkendelse i forhold til Lunas oplevelse af transformativ læring. Ved slutningen af 3.g identificerer Luna nogle punkter, der har betydning for hendes oplevelse af, at vejledningen bidrager til udviklingen af hendes opgave. I forhold til vejlederroller peger empirien på, at en variation i brugen af vejlederroller er hensigtsmæssig. Således fortæller Luna om, at både en instruktiv og en udfordrende vejledningsdidaktik har været meningsfuld i processen. Det er dog værd at fremhæve, at den instruktive vejlederrolle opleves meningsfuld $\mathrm{i}$ alle dele af vejledningsprocessen, og i den forbindelse peger Luna på tilgængelighed som væsentligt. Sideløbende med dette er der også et uudtalt ønske om, at vejledning skal tilgodese mere affektive elementer. I forhold til fokus for vejledning peger empirien på Lunas erkendelse af, at et tydeligt fokus, en fælles forståelse af formålet og et skriftligt forlæg, er centrale for oplevelsen af, at vejledning hjælper hende. Man kan måske netop antage, at skriftlige forlæg som genstand for vejledningssamtalen kunne udgøre "et fælles tredje", der kunne tilføre vejledningen en sammenhængskraft og et tydeligt fokus.

\section{Analyse - Fortællinger om vejledning fra en 1. årsstuderende}

\section{Præsentation af casen}

Det følgende er en præsentation af de væsentligste fund i tilknytning til den vejledning, Veronika modtager i forbindelse med arbejdet med de skriftlige opgaver på første år på danskstudiet. ÆErindet med analysen er både at vise, hvilke erfaringer Veronika kommer med fra gymnasiet, samt undersøge, hvordan de adresseres, og hvordan vejledning erfares i den nye institutionelle ramme.

Analyserne i afhandlingen viser, at Veronika i gymnasiet identificerer sig stærkt med den faglige kultur på danskstudiet, og at hun her ændrer sit meningsperspektiv, blandt andet ved at danne en stærk, selvstændig, faglig stemme (Drejer, 2018). Veronika starter på bacheloruddannelsen med vejledningserfaringer fra gymnasiet, der er knyttet til tekstnær, individuel vejledning. I overgangen til bacheloruddannelsen identificerer Veronika sig igennem det første år gradvist stærkere med den faglige kultur på universitetet. Samtidig identificerer hun sig som en studerende, der befinder sig i en indkultureringsproces, og som kritisk reflekterer over skrivning og sin udvikling som deltager i faget, og som er åben for vejlederens feedback. Veronika peger selv i interviews på, at individuel vejledning og feedback tæt knyttet til skriftlige opgaver, herunder til genre og faglig diskurs, i høj grad har bidraget til denne transformation. Nedenstående analyse udpeger, hvordan vejledningen på første år af bacheloruddannelsen har bidraget til Veronikas indkulturering. 
Vejledningshændelser i tilknytning til Veronikas skriveproces

\begin{tabular}{|c|c|c|c|c|}
\hline & $\begin{array}{l}\text { Tidspunkt og } \\
\text { varighed }\end{array}$ & Deltagere & $\begin{array}{l}\text { Lokale } \\
\text { organisatoriske } \\
\text { rammer og krav }\end{array}$ & Fokus i samtalen \\
\hline $\begin{array}{l}\text { Første } \\
\text { vejledning }\end{array}$ & $\begin{array}{l}05.11 .2015 \\
\text { Efter den første } \\
\text { opgave i litterær } \\
\text { analyse på } \\
\text { bachelorstudiet og } \\
\text { inden den anden } \\
\text { opgave på dette } \\
\text { kursus. Den } \\
\text { studerende } \\
\text { medbringer udkast til } \\
\text { opgaven. } \\
15 \text { minutter }\end{array}$ & $\begin{array}{l}\text { Vejlederen samt den } \\
\text { studerende }\end{array}$ & $\begin{array}{l}\text { Forudgående instruks } \\
\text { om roller i } \\
\text { vejledningen: Den } \\
\text { studerende skal være } \\
\text { aktivt lyttende og åben } \\
\text { samt overveje fokus i } \\
\text { feedbacken. }\end{array}$ & $\begin{array}{l}\text { Fokus for samtalen er } \\
\text { feedback på genre og } \\
\text { faglig diskurs i den } \\
\text { studerendes første } \\
\text { opgave. }\end{array}$ \\
\hline $\begin{array}{l}\text { Anden } \\
\text { vejledning }\end{array}$ & $\begin{array}{l}21.04 .2016 \\
\text { Efter den tredje } \\
\text { opgave i litterær } \\
\text { analyse på } \\
\text { bachelorstudiet og } \\
\text { inden den fjerde og } \\
\text { sidste i disciplinen. } \\
\text { Den studerende } \\
\text { medbringer } \\
\text { disposition til } \\
\text { opgaven. } \\
15 \text { minutter }\end{array}$ & $\begin{array}{l}\text { Vejlederen samt den } \\
\text { studerende. }\end{array}$ & $\begin{array}{l}\text { Ingen instrukser for } \\
\text { samtalen. }\end{array}$ & $\begin{array}{l}\text { Fokus for samtalen er } \\
\text { feedback på faglig } \\
\text { diskurs, metoder og } \\
\text { teorier i den } \\
\text { studerendes tredie } \\
\text { opgave. }\end{array}$ \\
\hline
\end{tabular}

Tabel 2: Rammer og indhold for vejledningshændelser knyttet til Veronikas første år på danskstudiet

\section{Hvilke indikatorer ser vi for udvikling i vejledning af skriveprocesserne?}

De to vejledninger, Veronika deltager i, har samme karakter: Der er tale om samtaler om større opgaver, som Veronika skriver på henholdsvis første og andet semester. Ved begge vejledninger er Veronikas opgaver i fokus. Desuden er begge vejledninger karakteriserede ved, at de er konkret handlingsanvisende og dermed peger fremad mod den næste opgave, Veronika skal skrive. Endelig er der i begge vejledninger fokus på faglig indkulturering og på ændring af meningsperspektiv gennem fokus på Veronikas fagligt-skriftlige ressourcer, herunder forståelse af genre, anvendelse af faglige begreber, metoder og teorier. 
I den første vejledning lægger vejlederen ud med at give feedback på skrivesituationen og genren:

Vejleder: [...] du indleder med, hvor Rifbjerg har publiceret novellen og andre generelle betragtninger [...] pas på med at gøre det, det handler om tekstanalyse, og vi fralægger os forforståelse af teksten $[\ldots]$

Veronika: Hvordan skal vi lave i en indledning ellers?

Vejleder: I gymnasiet er undervisningen ikke så disciplinagtigt, men her på uni stiller vi skarpt [på] forskellige elementer, $\mathrm{fx}$ analyse. Men du gør det rigtigt i selve teksten.

I dialogen peger vejlederen på det forhold, at Veronika skriver bredt formidlende ved at placere den analyserede tekst i en almen kulturel ramme og forudsætter, at hendes læser skal introduceres til teksten. Dermed peger vejlederen også på, at Veronika fortsætter en skrivning, som hun har tilegnet sig og udviklet i gymnasiet: Vejlederen adresserer Veronikas meningsperspektiv med henblik på, at det kan blive kritisk reflekteret af den studerende. Veronika har antaget, at hun skal skrive en litterær analyse, som hun er vant til i gymnasiet, og hun trækker dermed på sine tidligere skriveerfaringer, som hun i gymnasiekontekst blev anerkendt for.

Veronika har i skrivningen af den første opgave og inden vejledningen foretaget en ikke-reflekteret handling $i$ den forstand, at hun har aktiveret skriveressourcer, som hun har udviklet i en anden faglig kontekst, nemlig i danskfaget i gymnasiet. Dette har Veronika gjort uden kritisk at reflektere ændringerne i den faglige kultur i overgangen til universitetet. Vejlederen italesætter ikke blot dette forhold, men udpeger også konkret $\mathrm{i}$ Veronikas tekstafsnit, hvor dette sker. Derved giver vejlederen Veronika mulighed for kritisk at reflektere og vurdere tidligere erfaringer fra en anden faglig kontekst. Denne kritiske refleksion giver Veronika mulighed for at udvikle sin faglige skrivning, og giver grundlag for en perspektivomdannelse.

I dialogen ses det, at Veronika spørger uddybende til vejlederens tematisering af dette forhold. Dermed viser passagen fra vejledningen et eksempel på optag: Vejlederen tager afsæt i en konkret passage i Veronikas tekst, og Veronika tager vejlederens pointe op og stiller et afklarende spørgsmål med henblik på at transformere sin faglige skrivning. Gennem optag udspiller der sig altså en dialog, som er rettet mod forandring i Veronikas fremtidige skrivehandlinger. Dialogen bliver potentielt produktiv ved at anvise en konkret retning i Veronikas indkultureringsproces (Dysthe 2003: 121). Veronika positionerer sig hermed i vejledningen som en aktiv deltager, der er åben over for feedback, og som ønsker blive indkultureret i faget. I den forstand trækker Veronika på de vejledningserfaringer, hun bringer med sig fra gymnasiet, hvor hun også udviklede sin faglige skrivning gennem tekstnær vejledning (Drejer 2018).

Den anden vejledningssekvens er karakteriseret ved en lignende dialogisk tilgang med optag som et centralt element. Også her er vejledningen tæt på teksten, konkret handlingsanvisende i forhold til skrivegenrer. Herved lægger dialogen op til at ændre meningsperspektivet hos Veronika:

Vejlederen: [...] formuler dig så præcist som muligt. Du kan komprimere din tekst, der er ingen grund til at forklare en jegfortæller. Så får du også en mere stram fremstilling. Man kommer til at signalere en ubeslutsomhed. Ved eksamensopgave bør du lave flere afsnit, evt. med overskrifter. Det er vigtigt, at du signalerer, at du har en klar struktur. I din metoderedegørelse får du fremstillet metoden fint. I eksamensopgaven bør du arbejde med at motivere dit metodeafsnit, ellers kan det godt blive to afsnit, der står hver for sig. 
Veronika: Er der noget, jeg kan gøre?

Vejlederen: Ja, du stiller spørgsmål: Hvorfor er det relevant at bruge den her metode, hvad kan metoden gøre? Så er det ikke bare et ritual, men der er formål. Så kommer du også til at virke metodisk mere reflekteret [...] Hvor meget tid bruger du på at omstrukturere din tekst?

Veronika: Det er lidt løbende.

Vejlederen: Jeg tror, at du skal bruge et par dage på at omstrukturere, så får du en mere stram opgave. Så viser du, at du skriver på et overblik. Er der noget, du vil spørge om? Har det været svært?

Veronikas første spørgsmål i denne passage illustrerer ønsket om perspektivomdannelse, idet hun ønsker at udvikle sin skrivning, men spørgsmålet er bredt og ufokuseret. Vejlederens optag er rettet mod konkrete skrivehandlinger og peger på formål og funktion, og derved åbner dialogen op for, at Veronika kan ændre sit meningsperspektiv.

I et senere interview bliver Veronika bedt om at udpege det centrale i den vejledning, hun har modtaget på første år. Her slår Veronika ned på denne passage som det væsentligste i vejledningen:

Veronika: Det var nok med hensyn til min indledning. I gymnasiet, der har vi fået den der ... tragten eller pyramiden ... og det skal vi ikke her. Her der skal vi bare fortælle, hvad vi egentlig vil i opgaven. På den ene side synes jeg, det er lidt træls, for det er fedt at skrive sådan nogle indledninger.

Citatet illustrerer, at Veronika oplever at befinde sig i en overgangsposition mellem de to uddannelseskontekster: På den ene side ønsker hun at ændre sit meningsperspektiv; hun vil udvikle sin akademiske skrivning og blive indkultureret i faget på universitetet. På den anden side er denne transformative læring et tab for hende, fordi hun forventes at afvikle tidligere tilegnede skriveressourcer. Men Veronika er bevidst om denne proces.

Senere i interviewet peger Veronika selv på, at hun har reflekteret og brugt vejlederens feedback:

Veronika: [...] jeg kiggede jo lidt på de kommentarer, hun [underviseren] havde givet, da jeg var til samtale med hende ... efterfølgende ... og prøvede at fokusere på at lade være med de ting, som hun sagde ikke var så gode, men blive ved med [det] som så virkede. Så ... fx indledningen, der prøvede jeg at lade være med at komme ind på noget med forfatter men bare fokuserede på min problemstilling.

Her udtrykker Veronika en kritisk refleksion og peger på en reflekteret handling i sin skrivning, som hun direkte kobler til vejledningen. En anden kritisk refleksion hos Veronika adresserer brugen af fagbegreber, som hun selv - og underviseren - udpeger som et centralt element $\mathrm{i}$ indkultureringens indhold. I den første vejledning fylder feedback på Veronikas brug af fagbegreber meget, og i det andet interview kommer hun ind på dette:

Veronika: ... hun [underviseren] har gjort meget $\mathrm{i}$, at de skal sidde fast ... fagbegreberne ... så vil jeg også sige, at mange af dem bare sidder der [...] men hvis jeg ligesom kan se, at det her har jeg hørt om før, eller det har jeg set i analysen af en anden novelle, så går jeg lige ind og tjekker mine noter, og hvis jeg ikke kan finde det dér, så de Prezi som [underviseren] har lagt op. 
Analyser af Veronikas opgaver viser, at hun konkret gennemgår en omfattende perspektivomdannelse, idet hun udvikler sine skriveressourcer med hensyn til akademisk genre og faglig diskurs (Drejer 2018). Veronika udvikler sig fra en delvist ikke-reflekteret position til en mere reflekteret position i forhold til overgangen til universitetet: Blandt andet med afsæt i vejledningen reflekterer Veronika over sine tidligere skriveerfaringer, og hun handler selvkritisk i forhold til dem. Dette er en indikator på udvikling i den forstand, at det viser, at Veronika gennem vejledningen ændrer sit meningsperspektiv og tilegner sig redskaber, der er væsentlige i hendes indkultureringsproces i faget i en akademisk kontekst.

\section{Andring i meningsperspektiv - erkendelse}

I det afsluttende interview med Veronika bliver hun spurgt, hvordan hun selv oplever den udvikling, hun har gennemgået på første år af sit studie:

Veronika: Jeg skriver nok lidt mere videnskabeligt [...] at det skal være klart og tydeligt, og at det ikke behøver at være så indviklet [...] Jeg tror bare, at det nu ligesom kommer til én, hvordan man skriver videnskabeligt, og at der ligesom er et formål med den her opgave. At det ikke bare er noget, jeg skriver for at skrive [...] jeg tror, at det er kommet i de forskellige fag, hvor vi har fat nogle forskellige skriveøvelser. De vejledninger vi har haft, at hun fortæller, hvad vi skal have fokus på, hvad vi har styr på, og hvad vi skal gøre bedre.

Veronika fremhæver flere forhold, der har haft betydning for hendes udvikling og for ændringen i meningsperspektivet: det er i Veronikas egen optik et samspil mellem erfaringer fra forskellige discipliner og den individuelle vejledning. En betingelse for, at samspillet mellem erfaringer fra andre discipliner og vejledningen kan bidrage til transformativ læring er, at Veronika reflekterer over og omsætter erfaringerne og feedbacken i konkrete skrivehandlinger. Dette bidrager den tekstnære, konkret handlingsanvisende feedback til. Herved kobler Veronika - i samspil med omgivelserne - tidligere og nuværende erfaringer sammen og skaber en form for kontinuitet i erfaringsdannelsen. Kontinuiteten betyder ikke, at perspektivomdannelsen er lineær eller at den finder sted i en jævn og uproblematisk udvikling, men snarere, at de forskellige elementer bliver reflekteret kritisk og vurderet i forhold til hinanden.

Veronikas fortælling om indkultureringsprocessen har strukturlighed med en klassisk sommerfuglemodel (Greimas, 1966 (1970)): Veronika starter i sin skrivning på bacheloruddannelsen "hjemme" i den forstand, hun aktiverer redskaber, som hun har tilegnet sig i gymnasial kontekst og trækker på skrivehandlinger, som hun har udviklet i danskfaget i gymnasiet. I mødet med undervisningen og feedbacken i starten af bachelorstudiet møder Veronika imidlertid modstand: Hun bliver ikke i samme grad som i gymnasiet anerkendt som deltager i faget, og hun skal til at tilegne sig nye faglige redskaber. I den individuelle, tekstnære vejledning tilbydes Veronika konkret hjælp til at udvikle sin skriftlighed og får herved anvist en mulig vej ind i faget i den nye, akademiske kontekst.

\section{Diskussion - opsamling og anbefalinger}

I denne artikel har vi fokuseret analysen af de vejledtes læring i vejledningen ved bl.a. at anvende Deweys udviklingsbegreb, Mezirovs begreb om transformativ læring og Dysthes begreb om optag. Herved har vi kunnet konkretisere og afgrænse vores analyse af komplekse fænomener, men det er klart, at der er forhold ved deltagernes læring i vejledningsprocessen, som ikke kommer til udtryk i optag. Systematiske observationsstudier af vejledningshændelser, med fokus på vejledningsdialogen, kunne bibringe feltet en viden om, hvordan 
vejledningsdialoger styrker, udfordrer eller svækker studerendes udvikling i opgaveskrivningsprocessen. Dette kunne fx undersøges gennem samtaleanalyse og analyse af talehandlinger. Dette er et oplagt fokus for fremtidig forskning af elevers og studerendes indkulturering igennem vejledning, idet man herved vil kunne få et dybere indblik $\mathrm{i}$ indkultureringens processer på mikroniveau.

Vi har gennem Lunas case vist eksempler på de erfaringer, elever bringer med sig fra gymnasiet, og gennem Veronikas case har vi peget på, hvordan de adskiller sig fra de nye erfaringer, men også, hvordan der i vejledningen kan etableres et rum for transformativ læring. Afslutningsvist vil vi diskutere, hvad vi kan lære af de vejledningserfaringer, eleverne kommer med fra gymnasiet, og give et bud på, hvilke udfordringer vejledere kan være opmærksomme på ved det institutionelle rammeskifte.

Analysen af Lunas narrativ peger på betydningen af tilgængelighed og tid, hjælp til valg af materialer samt inddragelse af skriftlige forlæg i vejledningen. Analysen viser samtidig også, at hun parallelt med sin faglige udvikling i vejledningen søger bekræftelse som deltager i den faglige kultur. Endelig viser analysen, at Lunas udviklingsbane ikke er en lineær proces, men derimod en sammensat, langsommelig bevægelse: Hun får ikke entydigt udviklet en position som indkultureret deltager i faget. På den ene side udvikler Luna sin selvstændige skrivning og deltagelse i vejledningen. På den anden side demonstrerer hun igennem hele sit 3-årige vejledningsforløb et ønske om tryghed og anerkendelse. Med denne analyse peger vi på, at indkultureringsprocessen ikke alene kan beskrives ved rekonstruktion af erfaring (Dewey) eller ved udvikling af meningsperspektiv (Mezirow). Hverken Dewey eller Mezirow ofrer interpersonelle dynamikker og positioneringer i vejledningen og skrivningen særlig opmærksomhed. Som analysen af Lunas case viser, kan netop disse forhold spille en væsentlig rolle i den lærendes indkulturering. Vi argumenterer for, at der ligger en opgave for forskning i vejledning og skrivning i systematisk at undersøge betydningen af anerkendelse i indkultureringsprocesser. En sådan undersøgelse kunne være teoretisk funderet på Honneths analyse af anerkendelsesbegrebets dialektik (Honneth 2008).

En mulig forklaring på, at Lunas udvikling som skriver og vejledt ikke ændrer væsentligt på hendes behov for tryghed og anerkendelse er, at hendes vejledning ikke konkret inddrager skriftlige forlæg, og at hun derfor ikke opnår klar indsigt i, hvornår og hvorfor hendes skrivning er fagligt anerkendelsesværdig. Derfor er det også en pointe, at vejledningen, også i gymnasiet, bør være tekstnær. Analysen af Veronikas narrativ viser netop, at en vejledning, hvor der eksplicit arbejdes med kontinuitet i erfaringsdannelsen, og hvor den studerende forventes og også selv ønsker at ændre sit meningsperspektiv, kan være et stærkt redskab i indkultureringen.

På baggrund af analyserne peger vi på, at der ikke nødvendigvis er en modsætning mellem "selvstændighed" og "stilladsering" (Simonsen \& Wichmann-Hansen 2019) i den studerendes bevægelse ind i den faglige kultur. Vores analyser viser, at en positionering af den vejledte som novice i indkultureringsprocessen er en frugtbar tilgang: Den studerende kan gennem vejledning stilladseres til en mere selvstændig deltagelse i faget. Vi argumenterer for en vejledning, der bidrager til den studerendes kritiske refleksion gennem adressering af tidligere erfaringer. Konkret betyder det, at vi argumenterer for, at eksempelvis en førsteårsstuderende bør positioneres som en novice, der er på vej ind i en akademisk kultur og ikke som en studerende, der allerede har indtaget en selvstændig position i akademia. Endelig viser vores analyser, at den vejledning, Veronika deltager i gennem det første år af sin bacheloruddannelse, i højere grad understøtter hendes faglige udvikling, fordi den er tekstnær og dermed konkret handlingsorienteret, og fordi den giver Veronika konkret mulighed for kritisk refleksion over sine tidligere erfaringer og meningsperspektiver.

Både Lunas og Veronikas udvikling kan opfattes som kritiske cases (Flyvbjerg, 2010): Begge cases repræsenterer deltagere, der tilegner sig det forventede faglige indhold, der identificerer sig med den faglige kultur, de er og 
bliver en del af, og begge personer anerkendes som deltagere i fagene. Hvis Luna og Veronika oplever indkultureringen som en udfordrende og ikke-lineær proces, så vil andre elever og studerende, der i mindre grad har tilegnet sig fagets indhold, formentlig også opleve indkultureringen som udfordrende. Dermed argumenterer vi for, at fundene fra analyserne af Luna og Veronika er relevante i bredere sammenhænge. Generaliserbare elementer i de to cases kan endvidere knyttes til det forhold, at en markant del af de studerende på de videregående uddannelser kommer fra STX, hvor de har gjort sig erfaringer med vejledning i samme institutionelle rammesætning. Analyserne af de to cases illustrerer, at vejledning af skriveprocesser er et tidsligt langstrakt fænomen og en proces, som fortsætter gennem hele uddannelsesforløbet. Dermed peger analyserne både tilbage på vejledningen i gymnasieskolen og frem mod vejledningsprocesser senere i uddannelsesforløbet. Det kan tilføjes, at eftersom gymnasiets studieforberedende sigte er særlig fremhævet i arbejdet med de store opgaver, så er viden om opgaver og opgavevejledning på de videregående uddannelser væsentlig for vejlederes praksis i gymnasieskolen. Ligeledes er viden om disse studieforberedende opgaver og de vejledningsprocesser, som er knyttet til disse, værdifuld for vejledere på de videregående uddannelser.

På baggrund af vores undersøgelse vil vi derfor pege på, at nedenstående punkter kan understøtte den studerendes udbytte af vejledning af skriveprocesser:

- Vejlederne skal facilitere reflekteret læring gennem (selv)kritisk refleksion rettet mod tidligere praktikker med henblik på perspektivomdannelse. Dette er en indkultureringsproces.

- Vejlederne skal hjælpe med at skabe kontinuitet i erfaringsdannelsen, men når de ikke møder den studerende med disse redskaber, kan det givetvis tilskrives, at de ikke har en viden om, hvad den studerendes forudsætninger er. Eller det kan tilskrives, at vejlederne ser et andet formål med vejledning.

- Vejlederne skal positionere vejledte i overgangen som novicer.

- Vejlederne skal integrere tekstnær vejledning, der konkret anviser, hvordan den vejledte kan udvikle sig. I casen fra universitetet ser vi denne.

- Vejlederne skal være tilgængelige.

- Vejlederne skal arbejde med tryghed i vejledningsrummet.

- Vejlederne skal italesætte overgangen og bevægelsen fra novice til ekspert eller deltager med henblik på indkulturering.

\section{Litteratur}

Ask, S. (2007). Vägar till ett akademiskt skriftspråk. Ph.D.-afhandling. Växjö University Press.

Bakhtin, M. M. \& M. Holquist (1981). The dialogic imagination: Four essays. Austin: University of Texas Press.

Bang-Larsen, A. (2021). Hvem sagde vejledning?. CEPRA-Striben, (27), s. 72-83.

https://doi.org/10.17896/UCN.cepra.n27.401

Bang-Larsen, A. (2021). Klyngevejledning - Kaos eller Quest?. Nordisk Tidsskrift I Veiledningspedagogikk, 6(1). https://doi.org/10.15845/ntvp.v6i1.3229

Bang-Larsen, A. \& Drejer, S.N. (2021). To elevers skriverudvikling. Artikel indsendt til publicering. 
Bastalich, W. (2017). Content and context in knowledge production: a critical review of doctoral supervision literature, Studies in Higher Education, 42:7, s. 1145-1157. DOI: 10.1080/03075079.2015.1079702

Bengtsen, S. S (2018). Refleksioner over vejledningens relationelle dimension: undersøgelse af universitetsvejledning i praksis. I: Lund, L. \& Thingholm, H. (red.): Empirisk didaktik: udfordringer, refleksioner og potentialer undersøgt i forskellige pædagogiske praksisser. Frederikshavn: Dafolo, s. 73-88.

Boud, D., \& A. Lee (2005). "'Peer Learning' as Pedagogic Discourse for Research Education." Studies in Higher Education 30: 501-16. DOI: 10.1080/03075070500249138

Castelló, M. \& Iñesta, A. (2012). Texts as Artifacts-in-Activity: Developing Authorial Identity and Academic Voice in Writing Academic Research Papers.

Dewey, J. (2000). "Erfaring og opdragelse". Viborg: Rosinante, Viborg.

Hardy, C. \& Clughen, L. (2012). "Writing at university: student and staff expectations and experiences". I L. CLUGHEN and C. HARDY, eds., Writing in the disciplines: building supportive cultures for student writing in UK higher education. Bingley: Emerald, s. 25-53.

Delamont, S., Parry, O. \& Atkinson, P. (1998). Creating a Delicate Balance: the doctoral supervisor's dilemmas, Teaching in Higher Education, 3:2, s. 157-172. DOI: 10.1080/1356215980030203

Dixon , K. \& H. Hanks (2010). From poster to PhD: The evolution of a literature review. I: The Routledge doctoral supervisor's companion: Supporting effective research in education and the social sciences, $\mathrm{M}$. Walker \& P.. Thomson, s. 51 - 65. London: Routledge.

Drejer, S. (2018). Overgange og udviklinger. To skriveres transition mellem gymnasium og universitet i fagene dansk og fysik. Ph.d.-afhandling, Institut for Kulturvidenskaber, SDU.

Dysthe, O. (1997). Det flerstemmige klasserum. Skrivning og samtale for at lære. Aarhus: Klim

Dysthe, Olga (2003). Dialogisk samspil og læring. Århus, Forlaget Klim.

Ebbensgaard, A., Jacobsen, J.C. \& Ulriksen, L. (2014). Overgangsproblemer mellem grundskole og gymnasium i fagene dansk, matematik og engelsk. IND's skriftserie nr. 37.

Emilsson, U. M., \& E. Johnsson (2007). "Supervision of Supervisors: On Developing Supervision in Postgraduate Education." Higher Education Research and Development 26: s. 163-179. DOI: 10.1080/07294360701310797

Flyvbjerg, B. (2010). Fem misforståelser om casestudiet (Five Misunderstandings about Case-Study Research). I Brinkmann, S. \& Tanggaard, L. (red.). Kvalitative metoder. København: Hans Reitzels Forlag, s. 463-487.

Frank, Arthur W. (2015). "Selves, Holding Their Own with Illness", Creative Dialogues: Narrative and Medicine, edited by I. Fernandes et al. Cambridge Scholars Publishing, 2015, s. 120-129. 
Gamoran, A., \& Nystrand, M. (1991). Background and instructional effects on achievement in eighth-grade English and social studies. Journal of Research on Adolescence, 1(3), s. 277-

300. https://doi.org/10.1207/s15327795jra0103 5

Gatfield, T. (2005). "An Investigation into PhD Supervisory Management Styles: Development of a Dynamic Conceptual Model and its Managerial Implications." Journal of Higher Education Policy and Management 27: s. 311-25. DOI: 10.1080/13600800500283585

Geertz, Clifford (1973). The interpretation of cultures: selected essays. New York: Basic Books.

Greimas, A.J. (1973). On Meaning: Selected Writings in Semiotic Theory. Theory and History of Literature, 38. Minneapolis, MN: University of Minnesota Press.

Holmegaard, H.T., Madsen, L.M. \& Ulriksen, L. (2014a). "A journey of negotiation and belonging: understanding students' transitions to science and engineering in higher education". C S S E, 9, s. 755-786.

Holmegaard, H.T., Madsen, L.M. \& Ulriksen, L. (2014b). "To Choose or Not to Choose Science: Constructions of desirable identities among young people considering a STEM higher education programme". International Journal of Science Education 36 (2), s. 186-215.

Honneth, A. (2008). Kamp om anerkendelse. København: Hans Reitzels Forlag.

Ivanič, R. (1998). Writing and Identity. The discoursal construction of identity in academic writing. Amsterdam: John Benjamins Publishing Company.

Kiley, M. 2011. "Developments in Research Supervisor Training: Causes and Responses." Studies in Higher Education 36: s. 585-599. DOI: 10.1080/03075079.2011.594595

Krogh, E. (2014). "Overgangen fra grundskole til gymnasium. En elevskrivers håndtering af skiftende skrivekulturer og positioneringer. I Andersson, P., Lyngfelt, A., Nordenstam, A., Widhe, O. (red.): Mångfaldens möjligheter. Litteratur- och språkdidaktik i Norden. University of Gothenburg, s. 156-180.

Krogh, E. (2016). De store formater: Et studie i skrive- og skriveudviklinger i undersøgende skrivning. I Krogh, E. \& Jakobsen, K.S. (red.). Skriverudviklinger i gymnasiet. Odense: Syddansk Universitetsforlag, s. 71-105.

Krogh, E., Christensen, T. \& Jakobsen, K. (2015). Elevskrivere i gymnasiefag. Odense: Syddansk Universitetsforlag.

Krogh, E. \& Hobel, P (2012). "'Årets bedste opgave": en analyse af en elevtekst i dens kontekst". Matre, S.; Sjøhelle, D.K. og Solheim, R. (red.). Teorier om tekst i møte med skolens lese- og skrivepraksiser. Oslo: Universitetsforlaget, s. 137-150.

Lea, M. (2012). "New Genres in the Academy: Issues of Practice, Meaning Making and Identity". I Selves and Texts in Academic Societies. Studies in Writing,vol. 24. Bingley: Emerald, s. 93-109. 
Lea, M. R. \& Brian V. Street (2006). The "Academic Literacies" Model: Theory and Applications, Theory Into Practice, 45:4, s. 368-377, DOI: 10.1207/s15430421tip4504 11

Lee, Anne. 2008. "How are Doctoral Students Supervised? Concepts of Doctoral Research Supervision". Studies in Higher Education 33: s. 267-81. DOI: 10.1080/03075070802049202

Lee, Alison, \& B. Green. 2009. "Supervision as Metaphor." Studies in Higher Education 34: s. 615-30.

DOI: $10.1080 / 03075070802597168$

Lillis, T.M. (2009). "Bringing Writers' Voices to writing research". I Carter, Lillis og Parkin (red.): Why Writing Matters: Issues of Access and Identity in Writing Research and Pedagogy, Studies in Written Language and Literacy, s. 169-187.

Lillis, T.M. (2008). "Ethnography as Method, Methodology, and "Deep Theorizing": Closing the Gap Between Text and Context in Academic Writing Research". I Written Communication 2008; 25; 353. SAGE Publications.

Lillis, T.M. (2001). Student Writing: Access, Regulation, Desire. London, New York: Routledge

Loseke, D.R. (2007). The Study of Identity as Cultural, Institutional, Organizational, and Personal Narratives: Theoretical and Empirical Integrations. The Sociological Quarterly, 48(4), s. 661-688.

Lunsford, A. \& Lunsford, K (2008). "'Mistakes Are a Fact of Life': A National Comparative Study". I College Composition and Communication, vol. 59 (4), s. 781-806.

Mezirow, J. (2012). "Hvordan kritisk refleksion fører til transformativ læring". I Illeris, K. (red.) 49 tekster om læring. Frederiksberg: Samfundslitteratur, s. 156-172.

Nelson, N. \& Castello, M (2012). "Academic Writing and Authorial Voice". I Castelló, M. \& Donahue, C. (red.). University Writing: Selves and Texts in Academic Societies. Studies in Writing, 24. Bingley: Emerald, s. 19-31.

Pearson, M. (2005). Framing research on doctoral education in Australia in a global context, Higher Education Research \& Development, 24:2, s. 119-134. DOI: $\underline{10.1080 / 07294360500062870}$

Pearson, M., \& A. Brew (2002). Research Training and Supervision Development. Studies in Higher Education 27: s. 135-50. DOI: 10.1080/03075070220119986c

Prior, P. \& Bilbro, R. (2012). Academic Enculturation: Developing Literate Practices and Disciplinary Identities. I Castelló, M. \& Donahue, C. (red.). University Writing: Selves and Texts in Academic Societies. Studies in Writing, 24. Bingley: Emerald, s. 19-31.

Riessman, C.K. (2008). Narrative Methods for the Human Sciences. Thousand Oaks, CA: Sage.

Simonsen, K.B. \& Wichmann-Hansen, G. (2019). "Udvikling af studerendes selvstændighed: Stilladsering i bachelorvejledning". DUT årgang 15, nr. 27.

Sommers, N. \& Saltz, L. (2004). The Novice as Expert: Writing the Freshman Year. College Composition and Communication, 56(1), s. 124-149. 
Street, B. \& Robinson-Pant, A. (2012). "Students' and Tutors' Understanding of "New" Academic Literacies Practices". I Castollo \& Donahue (red.): University Writing. Selves and Texts in Academic Societies. Studies in Writing vol. 24. Bingley: Emerald.

Undervisningsministeriet. (2017). Læreplan - Studieretningsprojektet 2017. STX - læreplaner af 01/08/2017.

Wichmann-Hansen, G., Eika, B., \& Mørcke, A. M. (2007). Hvad findes der af litteratur om vejledning? Litteratursøgning med fokus på publicerede, evidensbaserede studier. Dansk Universitetspædagogisk Tidsskrift, 2(3), s. 11-19. Hentet fra https://tidsskrift.dk/dut/article/view/5636

Yin, R. K. (2011). Qualitative research from start to finish. The Guilford Press.

Zeuner, L. (2010). Interdisciplinære erkendelsesprocesser. I Zeuner, L., Beck, S., Frederiksen, L.F., Paulsen, M. \& Sørensen, E.K. (red.). Ret og gyldighed i gymnasiet: Fjerde delrapport fra forskningsprojektet Nye lærerroller efter 2005-reformen (s. 449-472). Gymnasiepædagogik, 76. Odense: Syddansk Universitet, Institut for Filosofi, Pædagogik og Religionsstudier.

\section{Betingelser for brug af denne artikel}

Denne artikel er omfattet af ophavsretsloven, og der må citeres fra den.

Følgende betingelser skal dog være opfyldt:

- Citatet skal være i overensstemmelse med "god skik"

- Der må kun citeres „i det omfang, som betinges af formålet”

- Ophavsmanden til teksten skal krediteres, og kilden skal angives ift. ovenstående bibliografiske oplysninger 